\title{
The creation of the International Astronomical Union as a result of scientific diplomacy
}

\author{
Arnaud Saint-Martin \\ Centre Alexandre Koyré, \\ École des Hautes Études en Sciences Sociales, 57, rue Cuvier, 75231 Paris cedex 05, France \\ email: arsaint-martin@orange.fr
}

\begin{abstract}
After World War I, the foundation of the International Astronomical Union delimited a space for a new form of internationality, which led to a rapid change in the way astronomical research had previously been pursued. This structure was to be a sort of parliament of astronomical nations which planned to supervise scientific programs and to rationalise inter-observatory cooperation. In this article, I will discuss the sociological aspects of this institutional process and introduce the idea of 'scientific diplomacy'.
\end{abstract}

Keywords. astronomy, diplomacy, international relations

\section{Introduction}

The International Astronomical Union (IAU) was founded in 1919 as an immediate result of the collective intention to federate allied astronomers in a new international organisation dedicated to astronomical researches, from which the Germans were excluded at the beginning. Since the first personal negotiations between several leaders of astronomy that took place between 1918 and the first congress of Rome in April 1922, a very restricted social space emerged, a sort of international parliament for astronomy which symbolised a significant linking of science and politics in the Post-Versailles period. So many things have been already said on the history of the IAU that it is impossible to give a comprehensive historical résumé. For instance, one may read Adrian Blaauw's authorised history of the first half-century of the IAU (Blaauw 1994) or the many other studies on the different organisations linked to the Union such as the International Research Council, the International Union for Geodesy and Geophysics, and the International Mathematical Union (see Greenway 1996) without mentioning the historiography of international science (Crawford et al. 1992; Drori et al. 2003; Polanco 1990). Given this documentation, the aim of this article is not to give a full account of what happened during the brief moment of the foundation. Instead I will address general questions about the early creation of the IAU. I will introduce the idea of the IAU as an institutional and ideological expression of scientific diplomacy, that is to say a specific sociocultural phenomenon rooted to the internationalisation of science in the twentieth century that should be studied for itself. Scientific diplomacy is a practical commitment related to a cultural disposition. It is not simply an ideological or discursive component: it is a general form of involvement that deeply influences the behaviour of those astronomers who were socially able (or in the position) to have an effect on the organisation. This is a nearly full-time activity driven by a differentiated repertoire of norms and values which shapes the configuration of a social structure on which I will give some in-formation later. There was nothing new under the sun since scientific diplomacy was already a 
moral responsibility, an intellectual ambition, and occasionally a duty for men of science during the nineteenth century (Cahan 2003); but in this particular historical context, scientists officially endorsed the role of ambassador or diplomatic agent of their country (see Schroeder-Gudehus 1978). This had important consequences on the scientific and institutional developments of professional astronomy in the decades that followed.

\section{Scientific diplomacy in perspective}

As self-proclaimed diplomatic agents and servants of scientific internationalism, the leaders of astronomy felt that they had an important (national) mission to serve. Their concrete objective was to create a Union for (so-called) civilized "scientific nations". This political project was clearly assumed by George Hale, William Campbell, Arthur Schuster, Alfred Fowler, Frank Dyson, Émile Picard, Alfred Lacroix, Benjamin Baillaud, Georges Lecointe, or Giorgio Abetti -to name the main characters. The obsession to organise the many branches of astronomical research led to an umbrella organization: the Union consisted in a complicated association of commissions specialised in the study of particular scientific problems. Science diplomats were so convinced by the need of a unification of all scientific disciplines that they established a sophisticated structure dominated by the International Re-search Council. As Brigitte Schroeder-Gudehus (1978) has pointed out, a functionalist ideology of both science and international relations legitimated this epistemic ideal. Of course this organisational doctrine was already present before 1914, but it became deeply effective after WWI -so effective that some astronomers were afraid that an 'over-organization' strangled the plan for the Union. Organising astronomy like that was a very tricky task, since the leaders of the Union had to entangle past structures (for instance, the Carte du Ciel, the Union for Solar Research) and new ones (the Bureau International de l'Heure) in an adequate and acceptable bureaucratic framework. And there were endless discussions on the viability of such a structure, because it had to be perfect and solid enough to last a minimum ten-year follow-up period.

The most remarkable political element in the foundation of the IAU was the importance given to the country as a basic unit for the membership or adhesion. Before 1914, membership was accorded to individuals - amateurs included- and observatories (Saint-Martin 2008b). With this new organisation, governments had to contribute to the financing of the Union in proportion of their demography. Astronomers could take part to the works of the IAU only at the condition that their government gave them a delegation for that purpose: they were first members of a (scientific) nation, then of an international union. The idea of a 'scientific nation' resulted from this conception of national and international relations. This conception has been rightly interpreted by the historians of science as a radical form of nationalism (see Crawford 1992; Forman 1973). Under -or in spite of- the universalist banner of the IAU, astronomers were in reality struggling for the sake of their nation; and this is the very essence of the Pastorian internationalism: i.e., science ignores national frontiers, but men of science belong to a nation (Moulin 2004). There was no contradiction in this moral inclination, just the affirmation and adjustment of a dual but quite asymmetric commitment. These things are well-known: nationalist ideologies and values merged in the definition of the astronomical internationality in the 1920s.

The International Research Council was a kind of 'league of scientific nations', or at least it was the claim implicitly made by its instigators. Scientific diplomacy was influenced by the geopolitical and ideological environment of the 1920s. The interconnection of the International Research Council and the League of Nations illustrates this process. 
There was an obvious identity or structural homology (and not simply an analogy) in the way the two organisations were founded, to such a point that I understand the International Research Council as a duplication or an institutional avatar of the League of Nations -and by extension the IAU as a micro-replication. In this sense, it illustrates the mechanism of 'mimetic isomorphism' revealed by the neo-institutionalist theory in the sociology of organisations (DiMaggio \& Powell 1991), which explains how an organisation to model itself in reference to a successful or legitimate organisation. In this process, scientific diplomacy was the means by which science and politics finally converged. This strong thesis is perfectly compatible with the socio-historical researches which describe, for instance, the co-construction of a scientific space and a political régime was decisive in the rise of modern European science in the seventeenth-century(Shapin and Schaffer 1985) $\dagger$.

The work done by the astronomers on what they called the 'constitution' of the Union is a good illustration of the science-politics junction. The writing of the constitution was a crucial moment because every aspects of the scientific cooperation had to be formally settled (Saint-Martin 2008a). The constitution was a unified pattern of association eventually ratified by the governments. What is important here is to understand the significations of the words used by those who wrote the constitution. This is the task of a politically informed semantics to decode the sense(s) of words -in French- like minutes, articles, exposé des motifs, procès-verbaux, and so on; and one could add to that semiotic interpretations of the symbols used to that remind every member that he was part of an indivisible moral community. The administration of international astronomy implied a defined domain of discourse. These linguistic resources served very pragmatic purposes: they were used to lay down the foundations of a political arena for astronomy; words like bureau exécutif, assemblée générale, or commission are quite significant in this case. They formed a useful conceptual framework for the astronomers. These schemes were associated to formal operations related to the regulation of the emergent organization (conditions of access, membership, etc.).

\section{A new micro-social order}

'The local production of the global' is today a commonplace in social studies of science. The history of the IAU offers a good example of how a specific form of internationality and universalism was produced in the post-WWI period, what I will call the 'assembly of international astronomy' (i.e., inter-allied astronomy). This astronomy was a microsituational reality: to paraphrase the sociologist Randall Collins, the macro-level of the international organisation resulted in the "unfurling of the scroll of micro-situations" (Collins 1998). One considers a very concrete representation of "international astronomy" with the identification of the micro-patterns of interaction between all the individuals involved in the IAU - which is indeed a compact social space. The conclusion of this reasoning is that one must know precisely how the characters interacted in the social space, who they were, and what they wanted to achieve.

I said earlier that the leaders of international astronomy behaved like "ambassadors" of their own country. It tells a lot about their self-perception as an élite of international science, and above all as improvised and spontaneous government representatives. Few scientists were involved in the creation of the IAU. This was the crême de la crîme of 1920s

$\dagger$ Lamy (2008) uses the same scheme to interpret the constitution of the Carte du Ciel. There was an affinity between the way the program was being organised at its very beginning and some of the values of the French Third Republic. 
science. Astronomers had to possess a sufficient scientific credibility to participate in those debates. They had close interpersonal relations. The sociability linking them was deeply personal (Greenway 1996). It is a very important fact. The decisions and resolutions were made by correspondence. This micro-astronomical-community was truly republic of letters: an imaginary space that would transcend geographical distances. The exchange of letters was quite dense and intensified the creation of what Collins calls informal "chains of dependence". Astronomers were bound together by moral, intellectual and friendly ties. Their insistence on valorising the strength of personal ties is sociologically striking. In spite of the divergences and the conflicts that could occur, they all thought that science could develop only on a personal basis. This led to an interesting assemblage: the Union was at the same time a very formal organization imitating the League of Nations, and -in theory- a group of ideally equal friends of science.

However, the pacification of astronomy by the formal/informal scientific diplomacy could not eradicate the conflicts that periodically appeared. As interpreters of their own country's interests - or what they interpreted as such- astronomers struggled, sometimes with violence. The clash between Picard and the duo Hale-Schuster is well-known; one may recall as well the aggressiveness and obstinacy of the French men of science in the first meeting. Astronomers battled for centrality: centrality in the control of the resources which allowed ensuring power and influence; they also wanted to be (at) the center of attention in scientific and diplomatic negotiations. Thus a complete account of the early foundation of the IAU should focus on the tension between these contrary sociopsychological forces. The Union was a civilised space where emotional energy, ideological beliefs, and personal caprices could be canalised, rationalized, cooled down.

\section{Conclusion}

One may wonder what is "really" scientific in the story I told. That is true that astronomical issues have disappeared in my discussion. But I think that there is no better way to describe the atmosphere of the period, given that in the first years of the UAI, ideological controversies and diplomatic problems such as the inclusion-exclusion of the Neutrals were definitely more relevant than scientific debates. Or put in another way, scientific issues were deeply colored and influenced by political motives (and ulterior motives). There is nothing curious or shocking about that: the archives are full of correspondences and reports in which politics, ideology and science are undifferentiated in a very specific historical context. That is why the con-cept of a parliament for international astronomy must be analysed as a contingent institutional artifact. And above all, there was no internal necessity in this process or even in the idea of gathering people in such an association. What may seem natural to us, here and now, was partly new for the scientists of these times.

\section{References}

Blaauw, A. 1994, History of the IAU: The Birth and First Half-Century of the International Astronomical Union (Dordrecht: Kluwer)

Cahan, D. 2003, in Natural Philosophy to the Sciences. Writing the History of NineteenthCentury Science D. Cahan (ed) (Chicago: University of Chicago Press), p. 291

Collins, R. 1998, The Sociology of Philosophies: A Global Theory of Intellectual Change (Cambridge: Harvard University Press)

Crawford, E. 1992, Nationalism and Internationalism in Science, 1880-1939: Four Studies of the Nobel Population (Cambridge: Cambridge University Press) 
Crawford, E., Shinn, T., \& Sörlin, S. (eds) 1992, Denationalizing Science: The Contexts of International Scientific Practice (Dordrecht: Kluwer)

DiMaggio, P. \& Powell, W. 1991, in The New Institutionalism in Organizational Analysis, W. Powell and P. DiMaggio (eds), (Chicago: University of Chicago Press), p. 1

Drori, G., Meyer, J., Ramirez, F., \& Schofer, E. (eds) 2003, Science in the Modern World Polity: Institutionalization and Globalization (Stanford: Stanford University Press)

Forman, P. 1973, Isis, 64, 150

Greenway, F. 1996, Science International: A History of the International Council of Scientific Institutions (Cambridge: Cambridge University Press)

Lamy, J. 2008, La Carte du Ciel (Les Ulis: EDP Sciences)

Moulin, A. M. 2004, in Transnational Intellectual Networks: Forms of Academic Knowledge and the Search for Cultural Identities, C. Charle, J. Schriewer, P. Wagner (eds), (Frankfurt: Verlag Campus), p. 135

Polanco, X. 1990, Naissance et développement de la science-monde (Paris: La Découverte)

Saint-Martin, A. 2008a, L'office et le télescope. Une sociologie historique de l'astronomie française, 1900-1940, Doctoral dissertation (Paris: Université Paris-Sorbonne)

Saint-Martin, A. 2008b, Nuncius. Journal of the History of Science, 23, 91

Schroeder-Gudehus, B. 1978, La communauté scientifique internationale au cours des années 20 (Montréal : Presses de l'Université de Montréal)

Shapin, S. \& Schaffer, S. 1985, Leviathan and the Air-Pump: Hobbes, Boyle, and the Experimental Life (Princeton: Princeton University Press) 